\title{
Distribution of Genes Encoding Toxin, Adhesion, and Antibacterial Resistance Among Various SCCmec Types of Methicillin-Resistant Staphylococcus aureus Isolated From Intensive Care Unit, Tehran, Iran
}

\author{
Parnaz Abiri, ${ }^{1,2}$ Abbas Akhavan Sepahi, ${ }^{3}$ Hossein Goudarzi, ${ }^{4}$ and Mehdi Goudarzi ${ }^{1,4,}{ }^{*}$ \\ ${ }^{1}$ Infectious Diseases and Tropical Medicine Research Center, Shahid Beheshti University of Medical Sciences, Tehran, Iran \\ ${ }^{2}$ Department of Microbiology, Islamic Azad University, Science and Research Branch, Tehran, Iran \\ ${ }^{3}$ Department of Microbiology, Islamic Azad University, North Tehran Branch, Tehran, Iran \\ ${ }^{4}$ Department of Microbiology, School of Medicine, Shahid Beheshti University of Medical Sciences, Tehran, Iran \\ "Corresponding author: Mehdi Goudarzi, School of Medicine, Shahid Behesthi University of Medical Sciences, Koodak-yar St., Daneshjoo Blvd., Velenjak, Chamran HWY, Tehran, \\ Iran. Tel: +98-123108104, Fax: +98-2122439972, E-mail: gudarzim@yahoo.com
}

Received 2017 June 03; Revised 2017 August 29; Accepted 2017 September 22.

\begin{abstract}
Background: Most methicillin-resistant Staphylococcus aureus (MRSA) infections occur in health care settings; therefore, it is important to know about antimicrobial susceptibility, and carriage of virulence genes in S. aureus isolates.

Objectives: The current study aimed at determining the prevalence of genes coding antimicrobial resistance, toxins, and adhesion factors among various SCCmec types of MRSA isolated from intensive care units (ICUs).

Methods: From April 2016 to March 2017, a total of 200 MRSA species were isolated from various clinical samples of patients hospitalized in ICUs. The Kirby-Bauer disk diffusion method was employed to determine resistance pattern. Conventional polymerase chain reaction (PCR) assay was utilized to demonstrate antimicrobial resistance, toxins, and adhesion genes. Different SCCmec types of MRSA strains were determine by the multiplex PCR assay.

Results: Antibiotic susceptibility testing revealed that all the isolates were sensitive to linezolid, teicoplanin, and vancomycin. The frequency of high-level mupirocin-resistant MRSA was 5.5\%. The presence of resistance genes $\operatorname{ant}\left(4^{\prime}\right)-\operatorname{Ia}, \operatorname{aac}\left(6^{\prime}\right)-\operatorname{Ie} / \operatorname{aph}\left(2^{\prime \prime}\right)$, tetM, $m s r A$, ph(3')-IIIa, ermA, msrB, ermB, ermC, and mupA were detected 73.5\%, 60.5\%, 57.5\%, 37\%, 36.5\%, 34.5\%, 24\%, 17\%, 15\% and 5.5\%, respectively. The most prevalent adhesion genes were clfA (93.5\%) followed by clfB (90\%), fnbA (81.5\%), fnbB (77\%), can (51\%), ebp (46.5\%), and $b b p$ (2.5\%). The frequency of $e t b$, eta, $p v l$, and tst genes were $4.5 \%, 9.5 \%, 21.5 \%$, and $61.5 \%$, respectively. Inducible macrolide-lincosamidestreptogramin B (inducible MLSB resistance; $\mathrm{iMLS}_{\mathrm{B}}$ ), and constitutive $\mathrm{MLS}_{\mathrm{B}}\left(\mathrm{CMLS}_{\mathrm{B}}\right.$ ) phenotypes were observed in 88 (44\%) and 26 (13\%) isolates. Different SCCmec types comprising type III (56.5\%), type IV (25\%), type II (11\%) and type I (7.5\%) were identified among the MRSA strains.

Conclusions: Results of the current study showed a high prevalence of resistance to commonly used antibiotics that can be a serious threat to patients hospitalized in ICUs. Also, the current study findings showed that different SCCmec types causing nosocomial infections were associated with specific antimicrobial resistance, adhesion, and toxin gene profiles.
\end{abstract}

Keywords: Methicillin-Resistant Staphylococcus aureus, Intensive Care Unit, SCCmec, Staphylococcus aureus

\section{Background}

The incidence of nosocomial infections in high-risk hospital units such as the intensive care unit (ICU) is increasing annually and is an important public health challenge due to difficulties with treatment and implementation of infection control measures. Moreover, patients admitted to ICUs are 5 to 10 times more likely to acquire a nosocomial infection than those in general wards. It is documented that nosocomial infections can increase ICU, mortality, and hospital costs (1). A wide range of infectious agents are associated with nosocomial infections in ICUs, but it is reported that Gram-positive bacteria are more frequent than Gram-negative ones in this context $(2,3)$. Al- though the agents of nosocomial infections vary in incidence and type between different ICUs, Staphylococcus aureus is the most common cause of nosocomial infection considered to be linked to severe illness and death $(1,2)$.

In ICUs, due to the use of multiple antibiotic therapies, resistance to commonly used antibiotics is prevalent. The pathogenesis of methicillin-resistant S. aureus (MRSA) strains are related to the expression of different virulence factors including (i) toxins and enzymes such as staphylokinase, toxic shock syndrome toxin-1 (TST-1), hemolysin (alpha, beta, gamma, and delta), Panton-Valentine leukocidin (PVL), exfoliative toxins (eta, etb), staphylococcal enterotoxins (SEs), and lipase; (ii) adhesions such as collagen binding protein (can), clumping factor (clf), fibronectin 
binding protein $(f n b)$, and elastin-binding protein $(e b p)(2)$. During the past several decades, S. aureus has developed resistance to many commonly used antibiotics; therefore, nowadays infections associated with MRSA are considered as serious threats in ICUs (1).

Methicillin-resistance is mediated by the expression of $\beta$-lactamase or an altered form of penicillin-binding protein-2 (namely PBP2a, also referred to as PBP2') encoded by mecA gene. The mec gene is carried within staphylococcal cassette chromosome mec (SCCmec) (4). A complex of the SCCmec gene contains: a. mec gene complex and its regulators containing mecA gene, IS431mec, and regulatory genes, b. cassette chromosome recombinase (ccr) genes composed of recombinase genes $c c r A$ and $c c r B$ or $c c r C$ that encode recombinase and mediate the insertion and excitation of SCCmec into and from the chromosomes, and c. the Junkyard (J) area (J1, $J 2$, and J3), which, as a nonessential component of the cassette, is located between and around the mec and ccr complexes $(4,5)$.

Eleven different SCCmec (I-XI) types were identified based on the mec gene and ccr gene complexes. According to the literature, SCCmec types I, II, and III are mostly found among hospital-acquired MRSA (HA-MRSA), while SCCmec types IV and $V$ are the prominent types among communityacquired MRSA (CA-MRSA). These 2 MRSA groups can be distinguished by some of their virulence factors and also epidemiologic, phenotypic, and genotypic characteristics (1, $5,6)$. Methicillin-resistant $S$. aureus strains demonstrate a wide pattern of resistance to $\beta$-lactams and other therapeutic options such as macrolides, lincosamides, and aminoglycosides (7). Resistance to aminoglycosides is mediated by aminoglycoside-modifying enzymes (AMEs) such as aminoglycoside acetyl transferases (AACs), aminoglycoside phosphotransferases (APHs), and aminoglycoside nucleotidyl transferases (ANTs) $(8,9)$.

Mupirocin is used to treat different types of staphylococcal skin infections. Resistance to mupirocin is mediated by mupA and mupB genes (10). The macrolide antibiotics, as protein synthesis inhibitors, are widely employed to treat staphylococcal infections. Resistance to macrolides is mediated by erm genes with the ribosomal binding site modification mechanism and $m s r$ genes with active efflux mechanism (11-13). The emergence and spread of various types of antibacterial resistance genes contribute to the resistance problem and treatment failure (14).

\section{Objectives}

The current study aimed at (i) characterizing the antibiotic resistance pattern, toxin, and adhesion profiles of
MRSA isolated from ICUs and investigating these isolates by SCCmec typing.

\section{Methods}

\subsection{Ethics Statement}

The current study was approved by the ethics committee of Shahid Beheshti University of Medical Sciences, Tehran, Iran (IR.SBMU.SM.REC.1395.43770).

\subsection{Bacterial Isolation and MRSA Screening}

The current cross sectional study, conducted from April 2016 to March 2017, investigated 200 MRSA strains isolated from various clinical samples of patients hospitalized in ICUs. Methicillin-resistant S. aureus strains were isolated from wound ( $\mathrm{n}=86 ; 43 \%)$, blood $(\mathrm{n}=38 ; 19 \%)$, catheter $(\mathrm{n}=25 ; 12.5 \%)$, pus $(\mathrm{n}=21 ; 10.5 \%)$, urine $(\mathrm{n}=15$; $7.5 \%$ ), ear $(n=8 ; 4 \%)$, and body fluids $(n=7 ; 3.5 \%)$. The isolates were identified as $S$. aureus based on colony morphology, Gram staining, production of catalase, tube coagulase test, and growth patterns on mannitol salt agar and DNase plates. Staphylococcus aureus isolates were subjected to polymerase chain reaction (PCR) for the nucA gene (1). All strains were screened phenotypically for methicillin susceptibility using cefoxitin $(30 \mu \mathrm{g})$ and oxacillin $(1 \mu \mathrm{g})$ discs on Mueller-Hinton agar plates supplemented with $4 \%$ $\mathrm{NaCl}$ according to the guidelines of Clinical and Laboratory Standard Institute (CLSI) (15). All MRSA strains confirmed by phenotypic methods were subjected to PCR for mecA gene (16). Isolates confirmed as MRSA were stored in tryptic soy broth (TSB; Merck, Germany) containing 20\% glycerol at $-70^{\circ} \mathrm{C}$ for further molecular testing.

\subsection{Antibacterial Susceptibility Testing}

Antibiotic susceptibility was performed on all the isolates by the Kirby-Bauer disc diffusion procedure as recommended by CLSI for a panel of 16 antibiotics such as ciprofloxacin (CIP $5 \mu \mathrm{g}$ ), penicillin (PG $10 \mu \mathrm{g}$ ), ceftriaxone (CRO $30 \mu \mathrm{g}$ ), amikacin (AK $30 \mu \mathrm{g}$ ), kanamycin (K 30 $\mu \mathrm{g}$ ), tetracycline ( $30 \mu \mathrm{g}$ ), clindamycin (CD $2 \mu \mathrm{g}$ ), erythromycin (E 15 $\mu \mathrm{g}$ ), linezolid (LZD $30 \mu \mathrm{g}$ ), teicoplanin (TEC $30 \mu \mathrm{g}$ ), quinupristin-dalfopristin (SYN $15 \mu \mathrm{g}$ ), tobramycin (TN $10 \mu \mathrm{g}$ ), gentamicin (GM $10 \mu \mathrm{g}$ ), and trimethoprimsulfamethoxazole (TS $2.5 \mu \mathrm{g}$ ). The minimum inhibitory concentration (MIC) for vancomycin and mupirocin was determined with E-test strips (bioMerieux, France) based on the manufacturer's instructions. The D-test method was performed using clindamycin $(2 \mu \mathrm{g})$ and erythromycin (15 $\mu \mathrm{g})$ disks spaced 15 to $26 \mathrm{~mm}$ apart.

According to the CLSI guidelines, strains with flattening of the zone of inhibition adjacent to the erythromycin 
disk (D-zone) and/or any growth in well containing 4 $\mu \mathrm{g} / \mathrm{mL}$ erythromycin and $0.5 \mu \mathrm{g} / \mathrm{mL}$ clindamycin were classified as inducible macrolide-lincosamide-streptogramin $\mathrm{B}$ (inducible MLSB resistance; $\mathrm{iMLS}_{\mathrm{B}}$ ) resistance, while constitutive $\mathrm{MLS}_{\mathrm{B}}\left(\mathrm{CMLS}_{\mathrm{B}}\right)$ phenotype was defined as the isolates resistant to both erythromycin and clindamycin. Isolates with D-test negative pattern were classified as MSresistant phenotypes (15). Multidrug resistance (MDR) is defined as resistance to at least 3 or more unique antibiotic classes in addition to beta-lactams (17). All the antibiotic disks used in the current study were supplied by Mast, UK. Staphylococcus aureus ATCC25923 and ATCC29213 were used as the quality control strains in antimicrobial susceptibility testing experiments.

\subsection{Adhesion, Antibiotic Resistance, and Toxin Encoding Genes Detection}

Genes encoding adhesions (spa, can, bbp, ebp, fnbB, fnbA, clfB, clfA), drug resistances (ermA, ermB, ermC, mupA,

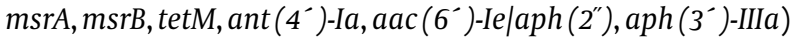
and toxins (etb, eta, pvl, tst) were targeted by PCR using specific primers listed in Table 1.

\subsection{Identification of SCCmec Types by Multiplex PCR}

The multiplex-PCR amplification was performed for SCCmec typing using specific primers previously described by Boy et al. (6). SCCmec types were identified by comparing the banding patterns of MRSA to ATCC 10442 (SCCmec type I), N315 (SCCmec type II), 85/2082 (SCCmec type III), MW2 (SCCmec type IVa), WIS (SCCmec type V), as the reference strains.

\section{Results}

\subsection{Antibiotic Resistance}

Antibiotic susceptibility testing was performed on 200 non-duplicate MRSA isolates. One hundred and ninetyfive (97.5\%) isolates were resistant to penicillin, 156 (78\%) to tetracycline, 155 (77.5\%) to kanamycin, 150 (75\%) to gentamicin, 114 (57\%) to erythromycin, 100 (50\%) to amikacin, 96 (48\%) to clindamycin, 90 (45\%) to ciprofloxacin, 86 (43\%) to tobramycin, $72(36 \%)$ to ceftriaxone, $36(18 \%)$ to mupirocin, $35(17.5 \%)$ to trimethoprim- sulfamethoxazole, and 19 (9.5\%) to quinupristin-dalfopristin. All of the isolates were susceptible to vancomycin, teicoplanin, and linezolid. The results of vancomycin MIC were as follows: 65 (32.5\%), 48 (24\%), and 87 (43.5\%) isolates had MICs of $0.5,1$, and $2 \mu \mathrm{g} / \mathrm{mL}$, respectively. In addition, 35 (17.5\%) MRSA isolates were resistant to mupirocin of which 11 (31.4\%) were high-level mupirocin- resistant (HLMUPR).
The results of antibiogram and MIC showed that 58 (29\%) isolates were susceptible to both clindamycin and erythromycin, $\mathrm{CMLS}_{\mathrm{B}}$ and $\mathrm{iMLS}_{\mathrm{B}}$ phenotypes were observed in 88 (44\%) and 26 (13\%) isolates, respectively. Finally, 8 (4\%) isolates were resistant to clindamycin and susceptible to erythromycin. The results of the susceptibility testing classified the MRSA strains into 9 groups. Antimicrobial susceptibility testing revealed that all the isolates were MDR. Resistance profiles and clinical samples isolated from patients hospitalized in ICU are presented in Table 2.

\subsection{The Distribution of Resistance Genes}

Among the investigated resistance genes, the most prevalent one was ant (4')-Ia (147; 73.5\%) followed by aac (6')-Ie/aph (2') (121; 60.5\%), tetM (115; 57.5\%), msrA (74; 37\%), aph (3`)-IIIa (73; 36.5\%), ermA (69; 34.5\%), msrB (48; 24\%), ermB ( $34 ; 17 \%)$, ermC (30; 15\%), and mupA (11; 5.5\%). Among 26 isolates with $\mathrm{iMLS}_{\mathrm{B}}$ resistance phenotype, ermA, ermB, erm $C, m s r A$, and $m s r B$ genes were detected in 20 (76.9\%), 18 (69.2\%), 12 (46\%), 10 (38.5\%) and 15 (57.7\%) isolates, respectively. Of the $88(44 \%)$ strains with the $\mathrm{CMLS}_{\mathrm{B}}$ phenotype, erm $A$, ermB, erm $C, m s r A$, and $m s r B$ genes were found in 45 (51.1\%), 15 (17.1\%), 18 (20.5\%), 48 (54.5\%), and 22 (25\%) isolates, respectively. Regarding the presence of aminoglycosideresistant genes, ant(4')-Ia was the most prevalent resistance gene (73.5\%) among the tested isolates. Co-existence of ant(4')-Ia and $\operatorname{aac}\left(6^{\prime}\right)-I e / \operatorname{aph}\left(2^{\prime \prime}\right)$ genes was detected in

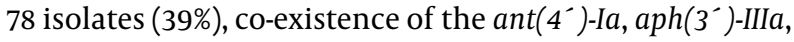
and $\operatorname{aac}\left(6^{\prime}\right)-\operatorname{Ie} / \operatorname{aph}\left(2^{\prime \prime}\right)$ in 38 isolates (19\%), ant(4')-Ia, and $\operatorname{aph}\left(3^{-}\right)$-IIIa in 30 isolates (15\%) and $\operatorname{aph}\left(3^{-}\right)$-IIIa, and aac(6 $\left.6^{-}\right)$Ie/aph(2") in 5 isolates (2.5\%). The $\operatorname{ant}\left(4^{\prime}\right)$-Ia gene was detected only in 1 isolate $(0.5 \%)$.

\subsection{Presence of Adhesion Encoding Genes}

With regard to the presence of genes coding for adhesions, the dominant gene was clfA (187; 93.5\%) followed by clfB (180; 90\%), fnbA (163; 81.5\%), fnbB (154; 77\%), can (102; 51\%), ebp (93; 46.5\%), and $b b p(5 ; 2.5 \%)$ genes. Distribution of adhesion genes among 200 MRSA strains isolated from patients hospitalized in ICUs is presented in Table 3.

\subsection{Detection of Toxin Encoding Genes}

Among the 200 MRSA isolates analyzed in the current study, the most frequent toxin genes were tst (123; 61.5\%), pvl (43; 21.5\%), eta (19; 9.5\%), and etb (9; 4.5\%), respectively. Distribution of toxin encoding genes among MRSA species isolated from clinical samples of patients hospitalized in ICU is presented in Table 3. 
Table 1. Primers Used in the Study

\begin{tabular}{|c|c|c|c|c|}
\hline Target & Primer & Primer Sequence $\left(5^{\prime} \rightarrow 3^{\prime}\right)$ & Product Size (bp) & Reference \\
\hline \multirow{2}{*}{ nucA } & $\mathrm{F}$ & GCGATTGATGGTGATACGGTT & \multirow{2}{*}{270} & \multirow{2}{*}{$(1)$} \\
\hline & $\mathrm{R}$ & AGCCAAGCCTTGACGAACTAAAGC & & \\
\hline \multirow{2}{*}{ mecA } & $\mathrm{F}$ & AGAAGATGGTATGTGGAAGTTAG & \multirow{2}{*}{583} & \multirow{2}{*}{ (16) } \\
\hline & $\mathrm{R}$ & ATGTATGTGCGATTGTATTGC & & \\
\hline \multirow{2}{*}{ luk-PV } & $\mathrm{F}$ & TTCACTATTTGTAAAAGTGTCAGACCCACT & \multirow{2}{*}{180} & \multirow{2}{*}{ (18) } \\
\hline & $\mathrm{R}$ & TACTAATGAATTTTTTTATCGTAAGCCCTT & & \\
\hline \multirow{2}{*}{ tsst-1 } & $\mathrm{F}$ & TTATCGTAAGCCCTTTGTTG & \multirow{2}{*}{398} & \multirow{2}{*}{ (16) } \\
\hline & $\mathrm{R}$ & TAAAGGTAGTTCTATTGGAGTAGG & & \\
\hline \multirow{2}{*}{ eta } & $\mathrm{F}$ & GCAGGTGTTGATTTAGCATT & \multirow{2}{*}{93} & \multirow{2}{*}{ (19) } \\
\hline & $\mathrm{R}$ & AGATGTCCCTATTTTTGCTG & & \\
\hline \multirow{2}{*}{ etb } & $\mathrm{F}$ & ACAAGCAAAAGAATACAGCG & \multirow{2}{*}{226} & \multirow{2}{*}{ (19) } \\
\hline & $\mathrm{R}$ & GTTTTTGGCTGCTTCTCTTG & & \\
\hline \multirow{2}{*}{ fnbA } & $\mathrm{F}$ & CACAACCAGC AAATATAG & \multirow{2}{*}{1362} & \multirow{2}{*}{$(2)$} \\
\hline & $\mathrm{R}$ & CTGTGTGGTAATCAATGTC & & \\
\hline \multirow{2}{*}{ fnbB } & $\mathrm{F}$ & GGAGAAGGAATTAAGGCG & \multirow{2}{*}{813} & (2) \\
\hline & $\mathrm{R}$ & GCCGTCGCCTTGAGCGT & & $(2)$ \\
\hline clfa & $\mathrm{F}$ & GTAGGTACGTTAATCGGTT & 1586 & (2) \\
\hline$=0$ & $\mathrm{R}$ & CTCATCAGGTTGTTCAGG & . & (1) \\
\hline clfB & $\mathrm{F}$ & TGCAAGATCAAACTGTTCCT & 596 & (2) \\
\hline & $\mathrm{R}$ & TCGGTCTGTAAATAAAGGTA & 390 & (2) \\
\hline cna & $\mathrm{F}$ & AGTGGTTACTAATACTG & 744 & (20) \\
\hline cina & $\mathrm{R}$ & CAG GAT AGA TTG GTTTA & 174 & קט \\
\hline bbp & $\mathrm{F}$ & CAGTAAATGTGTCAAAAGA & 1055 & $(21)$ \\
\hline & $\mathrm{R}$ & TACACCCTGTTGAACTG & בנד & $(21)$ \\
\hline ebp & $\mathrm{F}$ & CAATCGATAGACACAAATTC & 526 & $(21)$ \\
\hline P & $\mathrm{R}$ & CAGTTACATCATCATGTTTA & 320 & $(21)$ \\
\hline ant $\left(4^{\prime}\right)$-Ia & $\mathrm{F}$ & AATCGGTAGAAGCCCAA & 135 & $(14)$ \\
\hline & $\mathrm{R}$ & GCACCTGCCATTGCTA & 年 & \\
\hline $\operatorname{aac}\left(6^{\prime}\right)-\operatorname{Ie} / \operatorname{aph}\left(2^{\prime \prime}\right)$ & $\mathrm{F}$ & CCAAGAGCAATAAGGGCATACC & 222 & $(14)$ \\
\hline & $\mathrm{R}$ & CACACTATCATAACCACT & 222 & (14) \\
\hline $\operatorname{aph}\left(3^{-}\right)$-IIIa & $\mathrm{F}$ & CTTGATCGAAAAATACCGCTGC & 269 & (14) \\
\hline 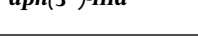 & $\mathrm{R}$ & TCATACTCTTCCGAGCAAA & 209 & (14) \\
\hline erm $A$ & $\mathrm{~F}$ & TATCTTATCGTTGAGAAGGGATT & 139 & (11) \\
\hline हाก & $\mathrm{R}$ & CTACACTTGGCTGATGAAA & S & (11) \\
\hline ermB & $\mathrm{F}$ & CTATCTGATTGTTGAAGAAGCATT & 141 & (11) \\
\hline eIIID & $\mathrm{R}$ & GTTTACTCTTGGTTTAGGATCAAA & 141 & (II) \\
\hline ermC & $\mathrm{F}$ & AATCGTCAATTCCTGCATGT & 299 & $(12)$ \\
\hline crime & $\mathrm{R}$ & TAATCGTGGAATACGGGTTTG & 293 & (12) \\
\hline msra & $\mathrm{F}$ & GGCACAATAAGAGTG TTTAAAGG & 940 & (13) \\
\hline & $\mathrm{R}$ & AAGTTATATCATGAATAGATTGTCCTGTT & 940 & (ID) \\
\hline$m s r B$ & $\mathrm{~F}$ & TATGATATCCATAATAATTATCCAATC & 595 & (13) \\
\hline עונדו & $\mathrm{R}$ & AAGTTATATCATGAATAGATTGTCCTGTT & 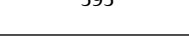 & (15) \\
\hline mupA & $\mathrm{F}$ & CCCATGGCTTACCAGTTGA & 1158 & $(10)$ \\
\hline тит & $\mathrm{R}$ & CCATGGAGCACTATCCGA & (1150 & (I0) \\
\hline tetM & $\mathrm{F}$ & AGTGGAGCGATTACAGAA & 158 & (19) \\
\hline 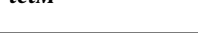 & $\mathrm{R}$ & CATATGTCCTGGCGTGTCTA & 150 & \\
\hline
\end{tabular}

\subsection{Distribution of SCCmec Types}

The multiplex-PCR to determine SCCmec types showed that 113 (56.5\%) isolates belonged to SCCmec type III, 50 (25\%) to SCCmec type IV, 22 (11\%) to SCCmec type II, and 15 (7.5\%) to SCCmec type I. It is noteworthy that all the isolates carrying pvl, eta, and etb encoding genes belonged to SCCmec IV, while isolates harboring tst-1 gene were distributed among SCCmec type III (40.7\%), SCCmec type IV
(35\%), SCCmec type II (14.6\%), and SCCmec type I (9.7\%). Of the 11 (5.5\%) HLMUPR-MRSA strains, 6 isolates (54.5\%) carried SCCmec type III, 4 isolates (36.4\%) SCCmec type II, and 1 isolate (9.1\%) SCCmec type I. Of the 26 isolates with iMLS $S_{B}$ phenotype, 17 isolates belonged to SCCmec type III (65.4\%) and $9(34.6 \%)$ to SCCmec type IV. Isolates with $\mathrm{CMLS}_{\mathrm{B}}$ phenotype were distributed among SCCmec type III (26;29.5\%), SCCmec type IV (25; 28.4\%), SCCmec type II (22; $25 \%)$, and SCCmec 
Table 2. Distribution of Different Clinical Samples and Resistance Profiles in MRSA Species Isolated From ICUs

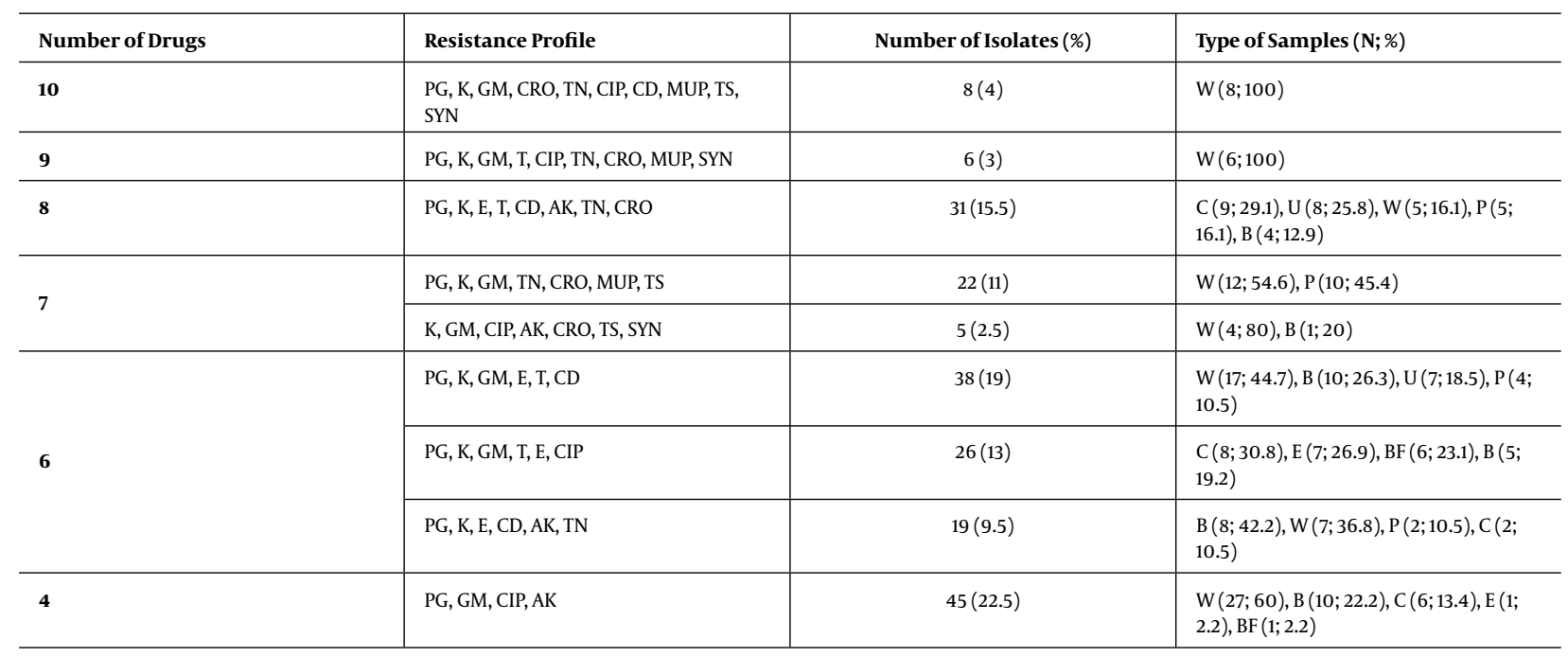

Abbreviations: AK, amikacin; B, blood; BF, body fluids; C, catheter; CD, clindamycin; CIP, ciprofloxacin; CRO, ceftriaxone; E, erythromycin; E, ear; GM, gentamicin; K, kanamycin; MUP, mupirocin; P, Pus; PG, penicillin; SYN, quinupristin-dalfopristin; T, tetracycline; TN, tobramycin; TS, trimethoprim-sulfamethoxazole; U, urine; W, wound.

type I (15; 17.1\%). The distribution of adhesion, toxin, and resistance encoding genes among different SCCmec types is summarized in Table 4.

\section{Discussion}

In the current study, wound (43\%) and blood (19\%) samples were the most common specimens in line with previous studies that reported MRSA isolates responsible for the majority of wound and blood infections in hospitalized patients $(2,14)$. The MRSA strains are usually resistant to macrolides, lincosamides, aminoglycoside, and approximately all currently available beta-lactam antimicrobial agents such as penicillin and cephalosporins (17, 22, 23). Accurate susceptibility data are important to appropriate treatment options. In the current study, the most resistant pattern among MRSA strains was observed in betalactam antibiotics including penicillin (97.5\%) followed by tetracycline (78\%), kanamycin (77.5\%), gentamicin (75\%), erythromycin 114 (57\%), amikacin (50\%), and clindamycin, while antibiotics such as vancomycin, teicoplanin, and linezolid had good activity against MRSA infections and these results were largely in line with the findings of Goudarzi et al., (23) and Ko et al. (24).

Although vancomycin-resistant $S$. aureus isolates are reported in many parts of the world, the results of susceptibility testing revealed that all isolates were susceptible to vancomycin and inhibited at $\leq 2 \mu \mathrm{g} / \mathrm{mL}$ consistent with other studies in Iran (25) and those of other countries (19,
26), which reported that MRSA was almost always susceptible to the mentioned antibiotics. This could be explained by the successful implementation of infection control programs and appropriate use of antibiotics in clinics. Aminoglycosides play a significant role in the treatment of numerous infections, especially staphylococcal infections. In line with the study by Ko et al. (24) and a study carried out in Iran by Rasahidi et al. (14) an increased resistance rate to aminoglycosides such as kanamycin (77.5\%), gentamycin (75\%), amikacin (50\%), and tobramycin (43\%) were also reported in the current study.

Molecular analysis of aminoglycosides resistance genes showed that ant (4')-Ia was dominant in $73.5 \%$ of the isolates followed by aac (6')-Ie/aph (2") (60.5\%) and aph (3-)-IIIa (6.5\%). Reported rate of ant (4')-Ia, which conferred resistance to kanamycin in the current study (73.5\%), was relatively higher than $42.2 \%$ reported from Iran by Rahimi et al. (27) and $24 \%$ by Ardic et al. (28) from Turkey. The majority of the isolates carrying this gene (90.3\%) were also resistant to kanamycin. The second most frequent AME detected in the current study was aac (6')-Ie/aph (2") (60.5\%), conferring gentamicin resistance, which was lower than the rate reported by previous study in Tehran, Iran (81.1\%) and higher than the ones reported in Turkey (28\%) (28).

In the current study, the rate of aph (3-)-IIIa (6.5\%) was relatively low, which was close to that of the study carried out in Japan (8.9\%) (29), but was lower than those of Turkey (66\%) (28) and Iran (19). In line with other 
Table 3. Virulence Patterns in MRSA Strains Isolated From Clinical Samples in ICUs

\begin{tabular}{|c|c|c|}
\hline Toxin Genes & $\mathbf{N}(\%)$ & Type of Samples (N;\%) \\
\hline tst, pvl, eta, etb & $5(2.5)$ & $\mathrm{W}(2 ; 40), \mathrm{B}(1 ; 20), \mathrm{C}(1 ; 20), \mathrm{BF}(1 ; 20)$ \\
\hline tst, pvl, eta & $14(7)$ & $\mathrm{B}(6 ; 42.9), \mathrm{W}(5 ; 35.7), \mathrm{P}(2 ; 14.2), \mathrm{C}(1 ; 7.2)$ \\
\hline tst, $p v l, e t b$ & $4(2)$ & $\mathrm{W}(4 ; 100)$ \\
\hline tst, pvl & $20(10)$ & $\mathrm{W}(8 ; 40), \mathrm{B}(4 ; 20), \mathrm{U}(3 ; 15), \mathrm{E}(3 ; 15), \mathrm{P}(2 ; 10)$ \\
\hline tst & $80(40)$ & $\mathrm{W}(30 ; 37.5), \mathrm{B}(15 ; 18.7), \mathrm{C}(11 ; 13.7), \mathrm{U}(9 ; 11.3), \mathrm{P}(8 ; 10), \mathrm{E}(5 ; 6.3), \mathrm{BF}(2 ; 2.5)$ \\
\hline \multicolumn{3}{|l|}{ Adhesion genes } \\
\hline clfA, clfB, fnbA, fnbB, can, ebp & $85(42.5)$ & $\mathrm{W}(49 ; 57.6), \mathrm{B}(10 ; 23.5), \mathrm{C}(9 ; 10.6), \mathrm{P}(7 ; 8.3)$ \\
\hline$c l f A, f n b A, f n b B, c a n, e b p, b b p$ & $4(2)$ & $\mathrm{W}(1 ; 25), \mathrm{BF}(2 ; 50), \mathrm{P}(1 ; 25)$ \\
\hline clfA, clfB, fnbA, can, ebp, bbp & $1(0.5)$ & $\mathrm{B}(1 ; 100)$ \\
\hline clfA, clfB, fnbA, fnbB & $63(31.5)$ & $\mathrm{W}(32 ; 50.8), \mathrm{B}(14 ; 22.2), \mathrm{C}(9 ; 14.3), \mathrm{U}(8 ; 12.7)$ \\
\hline clfA, clfB, fnbA, can & $10(5)$ & $\mathrm{C}(7 ; 70), \mathrm{W}(2 ; 20), \mathrm{U}(1 ; 10)$ \\
\hline$c l f A, f n b B, c a n, e b p$ & $2(1)$ & $\mathrm{W}(2 ; 100)$ \\
\hline clfA, clfB & $21(10.5)$ & $\mathrm{P}(10 ; 47.6), \mathrm{E}(5 ; 23.8), \mathrm{B}(3 ; 14.3), \mathrm{BF}(3 ; 14.3)$ \\
\hline$c l f A, e b p$ & $1(0.5)$ & $\mathrm{P}(1 ; 100)$ \\
\hline \multicolumn{3}{|l|}{ Resistance genes } \\
\hline $\operatorname{ant}\left(4^{-}\right)$-Ia, $\operatorname{aac}\left(6^{-}\right)-\operatorname{Ie} / \operatorname{aph}\left(2^{\prime \prime}\right), \operatorname{aph}\left(3^{-}\right)$-IIIa, tetM, ermA, ermB & $30(15)$ & $\mathrm{W}(15 ; 50), \mathrm{B}(10 ; 33.3), \mathrm{C}(2 ; 6.7), \mathrm{E}(3 ; 10)$ \\
\hline $\operatorname{ant}\left(4^{-}\right)-I a, \operatorname{aph}\left(3^{-}\right)$-IIIa, tetM, $m s r A$ & $30(15)$ & $\mathrm{W}(18 ; 60), \mathrm{B}(10 ; 33.3), \mathrm{C}(2 ; 6.7)$ \\
\hline $\operatorname{ant}\left(4^{-}\right)$-Ia, $\operatorname{aac}\left(6^{-}\right)$-Ie/aph(2"), tetM, ermA, ermC, $m s r A, m s r B$ & $28(14)$ & $\mathrm{W}(15 ; 53.6), \mathrm{B}(8 ; 28.6), \mathrm{C}(3 ; 10.7), \mathrm{P}(2 ; 7.1)$ \\
\hline $\operatorname{ant}\left(4^{\prime}\right)-\operatorname{Ia}, \operatorname{aac}\left(6^{\prime}\right)-\operatorname{Ie} / \operatorname{aph}\left(2^{\prime \prime}\right), \operatorname{tetM}$ & $22(11)$ & $\mathrm{W}(10 ; 45.5), \mathrm{B}(5 ; 22.7), \mathrm{C}(5 ; 22.7), \mathrm{E}(2 ; 9.1)$ \\
\hline $\operatorname{ant}\left(4^{\prime}\right)-\operatorname{Ia}, \operatorname{aac}\left(6^{\prime}\right)-\operatorname{Ie} / \operatorname{aph}\left(2^{\prime \prime}\right)$ & $19(9.5)$ & $\mathrm{W}(12 ; 63.2), \mathrm{B}(4 ; 21), \mathrm{BF}(2 ; 10.5), \mathrm{U}(1 ; 5.3)$ \\
\hline $\operatorname{ant}\left(4^{-}\right)-I a, \operatorname{aac}\left(6^{-}\right)-\operatorname{Ie} / \operatorname{aph}\left(2^{\prime \prime}\right), \operatorname{aph}\left(3^{-}\right)-I I I a, m u p A, m s r A, m s r B$ & $8(4)$ & $\mathrm{W}(8 ; 100)$ \\
\hline $\operatorname{ant}\left(4^{\prime}\right)-\operatorname{Ia}, \operatorname{aac}\left(6^{-}\right)-\operatorname{Ie} / \operatorname{aph}\left(2^{\prime \prime}\right), \operatorname{ermA}, m s r B$ & $6(3)$ & $\mathrm{W}(2 ; 33.3), \mathrm{C}(2 ; 33.3), \mathrm{U}(2 ; 33.3)$ \\
\hline $\operatorname{aac}\left(6^{\prime}\right)-\operatorname{Ie} / \operatorname{aph}\left(2^{\prime \prime}\right), \operatorname{aph}\left(3^{\prime}\right)-$ III a, ermA, $m s r A, m s r B$, tetM & $5(2.5)$ & $\mathrm{W}(2 ; 40), \mathrm{B}(1 ; 20), \mathrm{C}(1 ; 20), \mathrm{P}(1 ; 20)$ \\
\hline $\operatorname{ant}\left(4^{-}\right)-\operatorname{Ia}, \operatorname{aac}\left(6^{-}\right)-\operatorname{Ie} / \operatorname{aph}\left(2^{\prime \prime}\right), \operatorname{ermB}, \mathrm{msrA}$, mupA & $3(1.5)$ & $\mathrm{W}(3 ; 100)$ \\
\hline $\operatorname{ant}\left(4^{-}\right)$-Ia, ermC & $1(0.5)$ & $\mathrm{U}(1 ; 100)$ \\
\hline ermB, msrB, ermC & $1(0.5)$ & $W(1 ; 100)$ \\
\hline
\end{tabular}

Abbreviations: B, blood; BF, body fluids; C, catheter; E, ear; P, Pus; U, urine; W, wound.

studies, it was detected that gentamicin-susceptible isolates harbored $\operatorname{aac}\left(6^{\prime}\right) \mid a p h\left(2^{\prime \prime}\right)$ gene (4.1\%) and kanamycinsusceptible isolates harbored ant ( $\left.4^{\prime}\right)$-Ia gene (3.4\%). In contrast to the results of the study by Rahimi et al. (27) which reported $\operatorname{aac}\left(6^{\prime}\right) \mid \operatorname{aph}\left(2^{\prime \prime}\right)$ gene as the dominant AME gene in comparison to 2 others, ant $\left(4^{\prime}\right)$-Ia and aph( $\left.3^{\prime}\right)$-IIIa, it was determined that ant (4')-Ia gene was dominant in the current study isolates (73.5\%). Unfortunately, resistance to mupirocin as an effective antibiotic in eradication of nasal carriage of S. aureus and treatment of different types of staphylococcal skin infections is increasing (10).

The resistance rate to mupirocin varied from $17.5 \%$ in the current study to $25 \%$ in the previous study in Iran (30), $5 \%$ in India (31), 1.6\% in Greece (32), and 2.6\% in Jordan (33).
In the current study, 5.5\% of MRSA isolates carried mupA gene and were confirmed as HLMUPR MRSA. This finding was contrary to the observations reported from Iran by Shahsavan et al. (30) (25\%) and Gonzalez-Dominguez from Spain (34) (27.2\%). Low prevalence of HLMUPR MRSA strains was previously reported in Korea (1.8\%) (35). Unrestricted policies that allow improper and widespread utilization of mupirocin for long periods in hospitals and health care settings and the origin of the isolates and clinical samples are the most important causes of variation in the incidence rate of resistance to mupirocin in MRSA isolates (30-32). In all, the high resistance rate of mupirocin presented in the current study emphasized that using mupirocin in clinical practice should be modified. 
Table 4. Distribution of MRSA Virulence Genes Among Different SCCmec Types

\begin{tabular}{|c|c|c|c|c|c|}
\hline \multirow[t]{2}{*}{ Toxin, Adhesion and Resistance Gene } & \multicolumn{4}{|c|}{ Type of SCCmec } & \multirow[t]{2}{*}{ Total, N (\%) } \\
\hline & $\mathbf{I}, \mathbf{N}(\%)$ & II, N (\%) & III, N (\%) & IV, N (\%) & \\
\hline tst & $12(9.8)$ & $18(14.6)$ & $50(40.6)$ & $43(35)$ & $123(61.5)$ \\
\hline$p v l$ & $0(0)$ & $0(0)$ & $0(0)$ & $43(100)$ & $43(21.5)$ \\
\hline eta & $0(0)$ & $0(0)$ & $0(0)$ & $19(100)$ & $19(9.5)$ \\
\hline etb & $0(0)$ & $0(0)$ & $0(0)$ & $9(100)$ & $9(4.5)$ \\
\hline clfA & $12(6.5)$ & $18(9.6)$ & $110(58.8)$ & $47(25.1)$ & $187(93.5)$ \\
\hline clfB & $14(7.8)$ & $22(12.2)$ & $110(61.1)$ & 34 (18.9) & $180(90)$ \\
\hline fnbA & $9(5.5)$ & $19(11.7)$ & $89(54.6)$ & $46(28.2)$ & $163(81.5)$ \\
\hline fnbB & $15(9.8)$ & $21(13.6)$ & $80(51.9)$ & $38(24.7)$ & 154 (77) \\
\hline can & $11(10.8)$ & $14(13.7)$ & $31(30.4)$ & $46(45.1)$ & $102(51)$ \\
\hline ebp & $15(16.1)$ & $8(8.6)$ & $59(63.5)$ & $11(11.8)$ & $93(46.5)$ \\
\hline bbp & $1(20)$ & $1(20)$ & $1(20)$ & $2(40)$ & $5(2.5)$ \\
\hline ant (4-)-Ia & $5(3.4)$ & $9(6.1)$ & $83(56.5)$ & $50(34)$ & $147(73.5)$ \\
\hline $\operatorname{aac}\left(6^{\prime}\right)-\operatorname{Ie} / \operatorname{aph}\left(2^{\prime \prime}\right)$ & $8(6.6)$ & $14(11.6)$ & $74(61.1)$ & $25(20.7)$ & $121(60.5)$ \\
\hline tetM & $3(2.6)$ & $9(7.8)$ & $92(80)$ & $11(9.6)$ & $115(57.5)$ \\
\hline msrA & $5(6.7)$ & $17(23)$ & $43(58.1)$ & $9(12.2)$ & $74(37)$ \\
\hline $\operatorname{aph}\left(3^{\prime}\right)$-IIIa & $12(16.4)$ & $3(4.1)$ & $40(54.8)$ & $18(24.7)$ & $73(36.5)$ \\
\hline ermA & $8(11.6)$ & $19(27.5)$ & $19(27.5)$ & $23(33.4)$ & $69(34.5)$ \\
\hline$m s r B$ & $5(10.4)$ & $5(10.4)$ & $14(29.2)$ & $24(50)$ & $48(24)$ \\
\hline ermB & $12(35.3)$ & $0(0)$ & $13(38.2)$ & $9(26.5)$ & $34(17)$ \\
\hline ermC & $2(6.7)$ & $3(10)$ & $14(46.7)$ & $11(36.6)$ & $30(15)$ \\
\hline mupA & $1(9.1)$ & $4(36.4)$ & $6(54.5)$ & $0(0)$ & $11(5.5)$ \\
\hline Total & $15(7.5)$ & $22(11)$ & $113(56.5)$ & $50(25)$ & $200(100)$ \\
\hline
\end{tabular}

The macrolide antibiotics as a protein synthesis inhibitor are widely employed to treat staphylococcal infections. Based on in vitro susceptibility data, 114 (57\%) isolates were resistant to erythromycin and $96(48 \%)$ isolates resistant to clindamycin. The percentage of $i M L S_{B}$ resistance in the current study was relatively low (13\%), which was higher than the previous findings reported from Iran (4.18\%) (36) and USA (37) (7\%) and was lower than those of Turkey (18\%) (38) and Canada (35.3\%) (39). In line with other studies, an increased resistance rate of $\mathrm{CMLS}_{\mathrm{B}}$ phenotype was observed among the current study isolates (44\%). In the current study, the frequency of $\mathrm{CMLS}_{\mathrm{B}}$ phenotype was higher than that of iMLS $_{B}$ phenotype alongside the findings obtained by Ghanbari et al. (36). In the current study, the strains exhibiting $\mathrm{iMLS}_{\mathrm{B}}$ resistance phenotype carried the following genes: $\operatorname{erm} A(76.9 \%)$, ermB (69.2\%), ermC (46\%), $m s r A(38.5 \%)$, and $m s r B(57.7 \%)$.

The tetM was the third most commonly detected antibiotic resistance gene among the tested isolates, which in- cluded $57.5 \%$ of the strains. This finding was in line with those of Dormanesh et al. (40) that showed tetK (89.18\%), mecA (71.62\%), msrA (56.75\%), and tetM (54.05\%) as the most commonly detected antibiotic resistance genes in their study. As shown in Table 4, the most prevalent toxin encoding gene was tst (61.5\%), which was in agreement with those of the other studies $(1,22,23)$. In the current study, $p v$ l genes were detected in $21.5 \%$ of the tested isolates. Previous studies reported the prevalence of $2 \%$ to $35 \%$ of pvl genes among MRSA strains $(7,23)$. Regarding the frequency of the exfoliative toxins, the results revealed that eta was more common (9.5\%) than what was reported in Colombia (3\%) (41) and the previous study in Iran (2), while it was lower than the rate reported in Turkey (19.2\%) (42). In line with the current study findings, low frequency of etb gene was reported in several investigators $(41,42)$.

It was documented that biofilm formation in S. aureus is regulated by the expression of several adhesion genes. As shown in Table 4, the most prevalent gene was clfA (187; 
93.5\%) followed by clfB (180; 90\%), fnbA (163; 81.5\%), fnbB (154; $77 \%)$, can (102; 51\%), ebp (93; 46.5\%), and $b b p(5 ; 2.5 \%)$. This finding was in line with that of the study by Ghasemian et al. (43) reporting high prevalence of clfA and clfB genes in their study. Similar to the studies previously reported (2, 43 ), in the current study, the frequency of $f n b A$ and $f n b B$ genes were relatively high indicating the important role of these genes in colonization of MRSA. Results obtained in the current study showed that the frequencies of $e b p$ (46.5\%) and can (51\%) encoding genes were different from those of Ghasemian et al. (43) for can (78\%) and ebp (7\%) genes. This variation in the frequency of can and ebp genes in MRSA isolates can be described by the type of clinical isolates and factors affecting gene regulation, which may be important in the prevalence of these genes for colonization.

Regarding the frequency of SCCmec types, the current study results revealed that the majority of tested isolates belonged to SCCmec type III (56.5\%) followed by SCCmec type IV (25\%), SCCmec type II (11\%), and SCCmec type I (7.5\%). These findings were in agreement with the previous reports regarding the predominance of SCCmec III in most Asian countries (24), China (44) and Brazil (45). This SCCmec type was previously reported as the most prevalent type in Iran by several investigators $(46,47)$. High frequency of SCCmec type III in the current study highlighted the hospital origin of these strains. As mentioned earlier, SCCmec type IV was the second most-common SCCmec type identified in the current study (25\%). It is noteworthy that all the isolates carrying $p v l$, eta, and etb encoding genes belonged to this type, while isolates harboring tst-1 gene were distributed among different SCCmec types with the majority of SCCmec type III (40.7\%). It should be noted that resistance to antibiotics and MDR pattern were more prevalent among isolates with SCCmec type III than SCCmec type IV. These results confirmed similar observations reported by Ko et al. (24) and other studies (48-50).

\section{Conclusion}

In summary, the results of the current study indicated that SCCmec type III was predominant among MRSA strains isolated from patients hospitalized in ICUs. In general, it was observed that a coexistence of adhesion, resistance, and toxin genes could be associated with genetic background of the isolates. High occurrence of resistance genes among isolates emphasized that antibiotic resistance was still a major problem in hospitals and infection control measures should be prioritized in ICUs.

\section{Acknowledgments}

The current study was performed as part of master thesis by Mrs. Parnaz Abiri. Authors wish to thank the individuals and organizations participating in the current study.

\section{Footnote}

Funding/Support: This work was financially supported by a research grant from infectious diseases and tropical medicine research center, Shahid Beheshti University of Medical Sciences (grant No. 8410).

\section{References}

1. Goudarzi M, Goudarzi H, Sa Figueiredo AM, Udo EE, Fazeli M, Asadzadeh M, et al. Molecular Characterization of Methicillin Resistant Staphylococcus aureus Strains Isolated from Intensive Care Units in Iran: ST22-SCCmec IV/t790 Emerges as the Major Clone. PLoS One. 2016;11(5):0155529. doi: 10.1371/journal.pone.0155529. [PubMed: 27171373].

2. Eftekhar F, Rezaee R, Azad M, Azimi H, Goudarzi H, Goudarzi M. Distribution of adhesion and toxin genes in staphylococcus aureus strains recovered from hospitalized patients admitted to the ICU. Arch Pediatr Infect Dis. 2016;5(1) doi: 10.5812/pedinfect.39349.

3. Vandijck DM, Labeau SO, Vogelaers DP, Blot SI. Prevention of nosocomial infections in intensive care patients. Nurs Crit Care. 2010;15(5):251-6. doi: 10.1111/j.1478-5153.2010.00409.x. [PubMed: 20712670].

4. Ito T, Katayama Y, Asada K, Mori N, Tsutsumimoto K, Tiensasitorn C, et al. Structural comparison of three types of staphylococcal cassette chromosome mec integrated in the chromosome in methicillin-resistant Staphylococcus aureus. Antimicrob Agents Chemother. 2001;45(5):1323-36. doi: 10.1128/AAC.45.5.1323-1336.2001. [PubMed: 11302791].

5. Milheirico C, Oliveira DC, de Lencastre H. Update to the multiplex PCR strategy for assignment of mec element types in Staphylococcus aureus. Antimicrob Agents Chemother. 2007;51(9):3374-7. doi: 10.1128/AAC.00275-07. [PubMed: 17576837].

6. Boye K, Bartels MD, Andersen IS, Moller JA, Westh H. A new multiplex PCR for easy screening of methicillin-resistant Staphylococcus aureus SCCmec types I-V. Clin Microbiol Infect. 2007;13(7):725-7. doi: 10.1111/j.1469-0691.2007.01720.x. [PubMed: 17403127].

7. Goudarzi H, Seyedjavadi SS, E Udo E, Beiranvand E, Fazeli M, Goudarzi M. Molecular characterization and distribution of class 1 integron-bearing methicillin resistant staphylococcus aureus strains in burn patients, Tehran, Iran. Jundishapur J Microbiol. 2016;10(2) doi: 10.5812/jjm.40592.

8. Mahdiyoun SM, Kazemian H, Ahanjan M, Houri H, Goudarzi M. Frequency of Aminoglycoside-Resistance Genes in Methicillin-Resistant Staphylococcus aureus (MRSA) Isolates from Hospitalized Patients. Jundishapur J Microbiol. 2016;9(8):35052. doi: 10.5812/jjm.35052. [PubMed: 27800135].

9. Mahdiyoun SM, Ahanjan M, Goudarzi M, Rezaee R. Prevalence of antibiotic resistance in methicillin-resistant staphylococcus aureus and determining aminoglycoside resistance gene by PCR in Sari and Tehran hospitals. J Mazandaran Univ Med Sci. 2015;25(128):97-107.

10. Udo EE, Jacob LE, Mathew B. Genetic analysis of methicillin-resistant Staphylococcus aureus expressing high- and low-level mupirocin resistance. J Med Microbiol. 2001;50(10):909-15. doi: 10.1099/0022-131750-10-909. [PubMed: 11599741]. 
11. Martineau F, Picard FJ, Lansac N, Menard C, Roy PH, Ouellette M, et al. Correlation between the resistance genotype determined by multiplex PCR assays and the antibiotic susceptibility patterns of Staphylococcus aureus and Staphylococcus epidermidis. Antimicrob Agents Chemother. 2000;44(2):231-8. [PubMed: 10639342].

12. Strommenger B, Kettlitz C, Werner G, Witte W. Multiplex PCR assay for simultaneous detection of nine clinically relevant antibiotic resistance genes in Staphylococcus aureus. J Clin Microbiol. 2003;41(9):4089-94. [PubMed: 12958230].

13. Lina G, Quaglia A, Reverdy ME, Leclercq R, Vandenesch F, Etienne J. Distribution of genes encoding resistance to macrolides, lincosamides, and streptogramins among staphylococci. Antimicrob Agents Chemother. 1999;43(5):1062-6. [PubMed: 10223914].

14. Rasahidi Nezhad R, Meybodi SM, Rezaee R, Goudarzi M, Fazeli M. Molecular characterization and resistance profile of methicillin resistant staphylococcus aureus strains isolated from hospitalized patients in intensive care unit, Tehran-Iran. Jundishapur J Microbiol. 2017;10(3):41666. doi:10.5812/jjm.41666.

15. Clinical and Laboratory Standards Institute. . Performance standards for antimicrobial susceptibility testing; twenty-four informational supplement. 31. Clinical and Laboratory Standards Institute.; 2014. pp. M100-S24.

16. Azimian A, Havaei SA, Fazeli H, Naderi M, Ghazvini K, Samiee SM, et al. Genetic characterization of a vancomycin-resistant Staphylococcus aureus isolate from the respiratory tract of a patient in a university hospital in northeastern Iran. J Clin Microbiol. 2012;50(11):3581-5. doi: 10.1128/JCM.01727-12. [PubMed: 22933598].

17. Goudarzi M, Seyedjavadi SS, Azad M, Goudarzi H, Azimi H. Distribution of spa types, integrons and associated gene cassettes in staphylococcus aureus strains isolated from intensive care units of hospitals in Tehran, Iran. Arch Clin Infect Dis. 2016;11(4):38813.

18. Jarraud S, Mougel C, Thioulouse J, Lina G, Meugnier H, Forey F, et al. Relationships between Staphylococcus aureus genetic background, virulence factors, agr groups (alleles), and human disease. Infect Immun. 2002;70(2):631-41. [PubMed: 11796592].

19. Alfatemi SMH, Motamedifar M, Hadi N, Saraie HSE. Analysis of virulence genes among methicillin resistant Staphylococcus aureus (MRSA) strains. Jundishapur J Microbiol. 2014;7(6):10741. doi: 10.5812/jjm.10741.

20. Kumar JD, Negi YK, Gaur A, Khanna D. Detection of virulence genes in Staphylococcus aureus isolated from paper currency. Int J Infect Dis. 2009;13(6):450-5. doi:10.1016/j.ijid.2009.02.020. [PubMed:19477670].

21. Peacock SJ, Moore CE, Justice A, Kantzanou M, Story L, Mackie K, et al. Virulent combinations of adhesin and toxin genes in natural populations of Staphylococcus aureus. Infect Immun. 2002;70(9):4987-96. [PubMed: 12183545].

22. Goudarzi M, Bahramian M, Satarzadeh Tabrizi M, Udo EE, Figueiredo AM, Fazeli M, et al. Genetic diversity of methicillin resistant Staphylococcus aureus strains isolated from burn patients in Iran: ST239SCCmec III/t037 emerges as the major clone. Microb Pathog. 2017;105:17. doi: 10.1016/j.micpath.2017.02.004. [PubMed: 28179118].

23. Goudarzi M, Seyedjavadi SS, Nasiri MJ, Goudarzi H, Sajadi Nia R, Dabiri H. Molecular characteristics of methicillin-resistant Staphylococcus aureus (MRSA) strains isolated from patients with bacteremia based on MLST, SCCmec, spa, and agr locus types analysis. Microb Pathog. 2017;104:328-35. doi: 10.1016/j.micpath.2017.01.055. [PubMed: 28159661].

24. Ko KS, Lee JY, Suh JY, Oh WS, Peck KR, Lee NY, et al. Distribution of major genotypes among methicillin-resistant Staphylococcus aureus clones in Asian countries. J Clin Microbiol. 2005;43(1):421-6. doi: 10.1128/JCM.43.1.421-426.2005. [PubMed:15635004].

25. Japoni-Nejad A, Rezazadeh M, Kazemian H, Fardmousavi N, van Belkum A, Ghaznavi-Rad E. Molecular characterization of the first community-acquired methicillin-resistant Staphylococcus aureus strains from Central Iran. Int J Infect Dis. 2013;17(11):949-54. doi: 10.1016/j.ijid.2013.03.023. [PubMed: 23706379].
26. Budimir A, Deurenberg RH, Bosnjak Z, Stobberingh EE, Cetkovic H, Kalenic S. A variant of the Southern German clone of methicillinresistant Staphylococcus aureus is predominant in Croatia. Clin Microbiol Infect. 2010;16(8):1077-83. doi:10.1111/j.1469-0691.2009.03042.x. [PubMed: 19732087].

27. Rahimi F. Characterization of Resistance to Aminoglycosides in Methicillin-Resistant Staphylococcus aureus Strains Isolated From a Tertiary Care Hospital in Tehran, Iran. Jundishapur J Microbiol. 2016;9(1):29237. doi: 10.5812/jjm.29237. [PubMed: 27099687].

28. Ardic N, Sareyyupoglu B, Ozyurt M, Haznedaroglu T, Ilga U. Investigation of aminoglycoside modifying enzyme genes in methicillinresistant staphylococci. Microbiol Res. 2006;161(1):49-54. doi: 10.1016/j.micres.2005.05.002. [PubMed: 16338590].

29. Ida T, Okamoto R, Shimauchi C, Okubo T, Kuga A, Inoue M. Identification of aminoglycoside-modifying enzymes by susceptibility testing: epidemiology of methicillin-resistant Staphylococcus aureus in Japan. J Clin Microbiol. 2001;39(9):3115-21. [PubMed: 11526138].

30. Shahsavan S, Emaneini M, Noorazar Khoshgnab B, Khoramian B, Asadollahi P, Aligholi M, et al. A high prevalence of mupirocin and macrolide resistance determinant among Staphylococcus aureus strains isolated from burnt patients. Burns. 2012;38(3):378-82. doi: 10.1016/j.burns.2011.09.004. [PubMed: 22040930].

31. Gadepalli R, Dhawan B, Mohanty S, Kapil A, Das BK, Chaudhry $\mathrm{R}$, et al. Mupirocin resistance in Staphylococcus aureus in an Indian hospital. Diagn Microbiol Infect Dis. 2007;58(1):125-7. doi: 10.1016/j.diagmicrobio.2006.10.012. [PubMed: 17240103].

32. Petinaki E, Spiliopoulou I, Kontos F, Maniati M, Bersos Z, Stakias $\mathrm{N}$, et al. Clonal dissemination of mupirocin-resistant staphylococci in Greek hospitals. J Antimicrob Chemother. 2004;53(1):105-8. doi: 10.1093/jac/dkh028. [PubMed:14657085].

33. Aqel AA, Ibrahim A, Shehabi A. Rare occurrence of mupirocin resistance among clinical Staphylococcus isolates in Jordan. Acta Microbiol Immunol Hung. 2012;59(2):239-47. doi: 10.1556/AMicr.59.2012.2.8. [PubMed: 22750783].

34. Gonzalez-Dominguez M, Seral C, Potel C, Saenz Y, Alvarez M, Torres $\mathrm{C}$, et al. Genotypic and phenotypic characterization of methicillinresistant Staphylococcus aureus (MRSA) clones with high-level mupirocin resistance. Diagn Microbiol Infect Dis. 2016;85(2):213-7. doi: 10.1016/j.diagmicrobio.2016.02.021. [PubMed: 27133306].

35. Park SH, Kim JK, Park K. In Vitro Antimicrobial Activities of Fusidic Acid and Retapamulin against Mupirocin- and MethicillinResistant Staphylococcus aureus. Ann Dermatol. 2015;27(5):551-6. doi: 10.5021/ad.2015.27.5.551. [PubMed: 26512169].

36. Ghanbari F, Ghajavand H, Havaei R, Jami MS, Khademi F, Heydari L, et al. Distribution of erm genes among Staphylococcus aureus isolates with inducible resistance to clindamycin in Isfahan, Iran. Adv Biomed Res. 2016;5:62. doi: 10.4103/2277-9175.179184. [PubMed: 27135031].

37. Schreckenberger PC, Ilendo E, Ristow KL. Incidence of constitutive and inducible clindamycin resistance in Staphylococcus aureus and coagulase-negative staphylococci in a community and a tertiary care hospital.JClin Microbiol. 2004;42(6):2777-9. doi:10.1128/JCM.42.6.27772779.2004. [PubMed: 15184468].

38. Debdas D, Joshi S. Incidence of clindamycin resistance in clinical isolates of Staphylococcus aureus. J Infect Dev Ctries. 2011;5(4):316-7. [PubMed: 21537077].

39. Lavallee C, Rouleau D, Gaudreau C, Roger M, Tsimiklis C, Locas MC, et al. Performance of an agar dilution method and a Vitek 2 card for detection of inducible clindamycin resistance in Staphylococcus spp. $J$ Clin Microbiol. 2010;48(4):1354-7. doi: 10.1128/JCM.01751-09. [PubMed: 20164285].

40. Dormanesh B, Siroosbakhat S, Khodaverdi Darian E, Afsharkhas L. Methicillin-Resistant Staphylococcus aureus Isolated From Various Types of Hospital Infections in Pediatrics: Panton-Valentine Leukocidin, Staphylococcal Chromosomal Cassette mec SCCmec Phenotypes and Antibiotic Resistance Properties. Jundishapur J Microbiol. 
2015;8(11):11341. doi: 10.5812/jjm.11341. [PubMed: 26862375].

41. Jimenez JN, Ocampo AM, Vanegas JM, Rodriguez EA, Garces CG, Patino LA, et al. Characterisation of virulence genes in methicillin susceptible and resistant Staphylococcus aureus isolates from a paediatric population in a university hospital of Medellin, Colombia. Mem Inst Oswaldo Cruz. 2011;106(8):980-5. [PubMed: 22241120].

42. Demir C, Aslantas O., Duran N., Ocak S., Ozer B. . Investigation of toxin genes in Staphylococcus aureus strains isolated in Mustafa Kemal university hospital. Turk J Med Sci. 2011;41(2):343-52. doi: 10.3906/sag1003-657.

43. Ghasemian A, Peerayeh SN, Bakhshi B, Mirzaee M. Several virulence factors of multidrug-resistant Staphylococcus aureus isolates from hospitalized patients in Tehran. Int J Enteric Pathog. 2015;3(2):25196. doi:10.17795/ijep25196.

44. Chen X, Yang HH, Huangfu YC, Wang WK, Liu Y, Ni YX, et al. Molecular epidemiologic analysis of Staphylococcus aureus isolated from four burn centers. Burns. 2012;38(5):738-42. doi:10.1016/j.burns.2011.12.023. [PubMed: 22360963].

45. Rodrigues MV, Fortaleza CM, Riboli DF, Rocha RS, Rocha C, da Cunha Mde L. Molecular epidemiology of methicillin-resistant Staphylococcus aureus in a burn unit from Brazil. Burns. 2013;39(6):1242-9. doi: 10.1016/j.burns.2013.02.006. [PubMed: 23597850].

46. Mohammadi S, Sekawi Z, Monjezi A, Maleki MH, Soroush S, Sadeghifard N, et al. Emergence of SCCmec type III with variable antimicro- bial resistance profiles and spa types among methicillin-resistant Staphylococcus aureus isolated from healthcare- and communityacquired infections in the west of Iran. Int J Infect Dis. 2014;25:152-8. doi: 10.1016/j.ijid.2014.02.018. [PubMed: 24909489].

47. Sadeghi J, Mansouri S. Molecular characterization and antibiotic resistance of clinical isolates of methicillin-resistant Staphylococcus aureus obtained from Southeast of Iran (Kerman). APMIS 2014;122(5):405-11. doi: 10.1111/apm.12158. [PubMed: 24033803].

48. Bayat B, Zade MH, Mansouri S, Kalantar E, Kabir K, Zahmatkesh E, et al. High frequency of methicillin-resistant Staphylococcus aureus (MRSA) with SCCmec type III and spa type t030 in Karaj's teaching hospitals, Iran. Acta Microbiol Immunol Hung. 2017;64(3):331-41. doi: 10.1556/030.64.2017.020. [PubMed: 28836817].

49. Parhizgari N, Khoramrooz SS, Malek Hosseini SA, Marashifard M Yazdanpanah M, Emaneini M, et al. High frequency of multidrugresistant Staphylococcus aureus with SCCmec type III and Spa types t037 and t631 isolated from burn patients in southwest of Iran. APMIS 2016;124(3):221-8. doi: 10.1111/apm.12493. [PubMed: 26709106].

50. Darban-Sarokhalil D, Khoramrooz SS, Marashifard M, Malek Hosseini SA, Parhizgari N, Yazdanpanah M, et al. Molecular characterization of Staphylococcus aureus isolates from southwest of Iran using spa and SCCmec typing methods. Microb Pathog. 2016;98:88-92. doi: 10.1016/j.micpath.2016.07.003. [PubMed: 27392699]. 